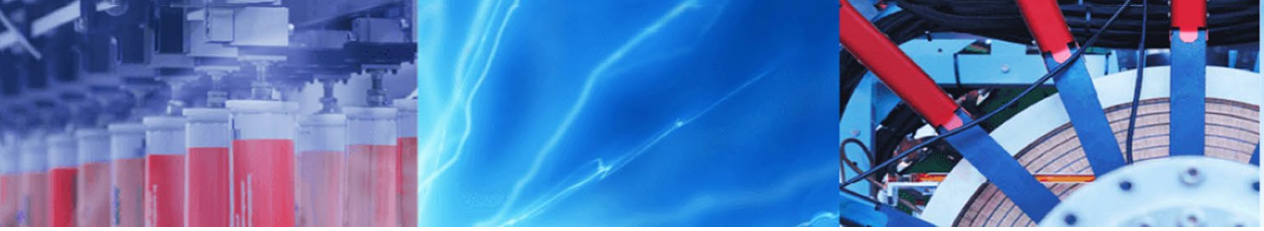

Research Article

\title{
Harnessing the potential of common water hyacinth as an industrial raw material for the production of quality biofuel briquettes
}

\author{
Janet Onyango ${ }^{1,2,3} \cdot$ Kelvin Babu $^{1,2,3} \cdot$ Samwel Njuguna ${ }^{1,2,3} \cdot$ Wycliffe Wanzala $^{4} \cdot$ Xue Yan $^{1,2,3}$
}

Received: 31 January 2020 / Accepted: 19 June 2020 / Published online: 1 July 2020

(c) Springer Nature Switzerland AG 2020

\begin{abstract}
Eichhornia crassipes has a high cellulose and hemicellulose content, which are easily converted to simple sugars, thus making the plant suitable for the production of biofuel briquettes. The main purpose of this proposed work, therefore, was to investigate the production of bio briquettes from E. crassipes. The plant was harvested from a wastewater effluent management system, chopped, sun-dried and pulverized to a particle size of $<5 \mathrm{~mm}$ and mixed with various binders (Eucalyptus globulus leaves powder, molasses and phytoplankton scum). The binders were appropriately prepared and added to $E$. crassipes at the ratios of $10 \%, 20 \%$ and $30 \%$. The quality of biofuel briquettes was evaluated using compressed density, relaxed density, water resistance, durability and calorific values (CV) parameters and compared to those of charcoal briquettes already on the market. The results showed a water resistance capacity of $45 \%$, relaxation ratios of between 1.08 and 1.33, CV of $1148.35 \mathrm{~kJ} / \mathrm{kg}$ for $20 \%$ molasses-based briquettes, CV of $1090.43 \mathrm{~kJ} / \mathrm{kg}$ for $20 \%$ E. globulus leaf-based briquettes and CV of $1422.97 \mathrm{~kJ} / \mathrm{kg}$ for charcoal-based briquettes. In conclusion, therefore, E. crassipes may become a viable raw material for producing quality biofuel briquettes that are durable with the desired calorific value and may be able to withstand mechanical handling and be useful for household and cottage industries locally.
\end{abstract}

Keywords Eichhornia crassipes - Biomass · Calorific value · Relaxation density · Water resistance capacity · Biofuel briquettes

\section{Introduction}

The common water hyacinth (Eichhornia crassipes (Mart.) Solms) is an aquatic weed of the Pontederiaceae family (Pickerelweed) and is found in almost all the continents of the world. The weed is reported to have originated from the Amazon basin $[1,2]$ and spread to other parts of the world as a prized ornamental plant for ponds, arboreta, aquaria and botanical gardens [3]. The weed has moderate to high growth rate and its seeds have a 15-20 years dormancy period where it blooms and spreads fast when the conditions are ideal $[4,5]$. The plant has purplish or lilac flowers, round leaves $[6,7]$ and reproduces vegetatively by budding and stolons and also sexually through its seeds [8]. Due to its dense complex root system, E. crassipes grows and spreads forming a mat over water, reducing oxygen and light penetration. The weed's high survival traits greatly influence its eradication strategies and are

Electronic supplementary material The online version of this article (https://doi.org/10.1007/s42452-020-3109-1) contains supplementary material, which is available to authorized users.

$\triangle$ Xue Yan, yanx@wbgcas.cn; Janet Onyango, janetonyango74@gmail.com; Kelvin Babu, babukelvin@gmail.com; Samwel Njuguna, smaina2005@gmail.com; Wycliffe Wanzala, wanzala@mmarau.ac.ke|' Key Laboratory of Aquatic Botany and Watershed Ecology, Wuhan Botanical Garden, Chinese Academy of Sciences, Wuhan 430074, China. ${ }^{2}$ Sino-Africa Joint Research Center, Chinese Academy of Sciences, Wuhan 430074, China. ${ }^{3}$ University of Chinese Academy of Sciences, Beijing 100049, China. ${ }^{4}$ The Institute of Ethnobiology and Ethnomedicines, Maasai Mara University, P.O. Box 861, Narok 20500, Kenya. 
instrumental for its ability to infest and colonize new ecosystems [2].

Several studies have been done on eradication, management and control of $E$. crassipes. The use of glyphosate herbicides, for instance, has been applied in Brazil and the USA with little success $[9,10]$. Nevertheless, positive results were recorded with the use of weevils for biocontrol of E. crassipes but after a long period [11]. Therefore, much of the eradication, management and control strategies of $E$. crassipes have largely not been successful. Economic utilization as a management strategy has been therefore encouraged worldwide. For instance, the positive use of the weed in the generation of farm fertilizer [12], production of bioethanol [13-15] substrate for mushrooms [16], generation of biogas energy $[5,7,17]$ and remediation of polluted water $[3,18,19]$ has been widely reported worldwide. E. crassipes has proved an efficient tool in cleaning sewage water as it absorbs nitrogen, phosphorus and other nutrients [19]. The younger plants uptake the nutrients at a faster rate, which decreases as the tissues become saturated [19]. The saturated older plants need to be regularly harvested to ensure the efficiency of the sewage cleaning system through maximum nutrient absorption.

Biomass fuel is energy derived from organic matter, which may include plant materials, agricultural wastes and also forest residues. Loose biomass and animal dung are inefficient during combustion as they produce smoke and cause a lot of pollution. Cellulose and hemicelluloses, which are the major components of E. crassipes biomass and are easily converted into simple sugars $[20,21]$ make $E$. crassipes ideal for generation of energy $[22,23]$. By using appropriate binders, E. crassipes has been reported to produce good biofuel briquettes [16]. The production of biofuel briquettes offers an alternative use of $E$. crassipes that is a more effective solution to its management strategy as an Invasive Alien Species (IAS) [6]. Briquetting technology produces safe and clean energy for the urban and peri-urban residents of the developing economies [23, 24]. Binders help improve the calorific values of biofuel briquettes [25], enhance bonding and formation of strong and more stable biofuel briquettes [26], which are easier to handle, transport and store. Density and strength of the biofuel briquettes are very important as poor quality biofuel briquettes can easily crumble and disintegrate [27] when stored, transported and/or handled in anyways [1]. Various materials such as forest residues, agricultural residues, livestock dung and municipal wastes have been explored in biofuel briquette production by various stakeholders [26]. However, much of the energy exploration of E. crassipes has concentrated on biogas production while biofuel briquette production has received little attention. This research, therefore, hypothesized to exploit the whole plant of $E$. crassipes mixed with various binders to produce quality biofuel briquettes by determining their physical qualities and the energy content as well as comparing their energy content to those of charcoal briquettes.

\section{Materials and methods}

\subsection{Study area}

The study site was at the African Medicinal Botanical Garden (AMBG) of the Maasai Mara University located in Narok County, Kenya (1.0960 S, 35.8553 E) (Fig. 1). The E. crassipes were obtained from Maasai Mara University Wastewater Effluent Management System (MWEMS) connected to AMBG as a source of purified water for managing the growing medicinal plant species as the location is in semi-arid parts of Kenya with unpredictable extreme water shortages.

The $E$. crassipes is biologically used to clean water in MWEMS. The cleaned water is re-used for managing the growing medicinal plant species at the AMBG. This has helped a great deal with the perennial water shortages earlier experienced at the university and with this research, comes to the hope of not only environmental conservation [19] but also economic gain through the use of harvested E. crassipes as raw material for the production of biofuel briquettes.

\subsection{The briquetting machine}

The briquetting machine was locally fabricated (Fig. 2). The machine was used to compact the biomass [24] as well as giving the biofuel briquettes their desired shape $[16,28]$. The machine consists of a 5 cc electric motor, switch box, a holding area for putting the biomass, a nozzle ( 3 inches) with a screw press ( 1 inch diameter) fitted inside the barrel, which creates a middle hole in the biofuel briquettes as well as a metallic body (Figs. 2, 3). The briquetting machine enhanced transportation and increased calorific value of biomass materials according to Okwu and Emovon [28]. When the machine is being operated and the screw press is turned on, it increases the density of the biomass material poured into the holding area (Fig. 2). The biofuel briquette mold is received at the nozzle (i.e. at the barrel end) (Fig. 2).

\subsection{Preparation of the materials}

The $E$. crassipes were manually harvested for four consecutive weeks from the Maasai Mara University Wastewater Effluent Management System (MWEMS) and subsequently chopped into small pieces, then sun-dried [1] to attain about $8.5 \%$ moisture content (Fig. 3). The collected 


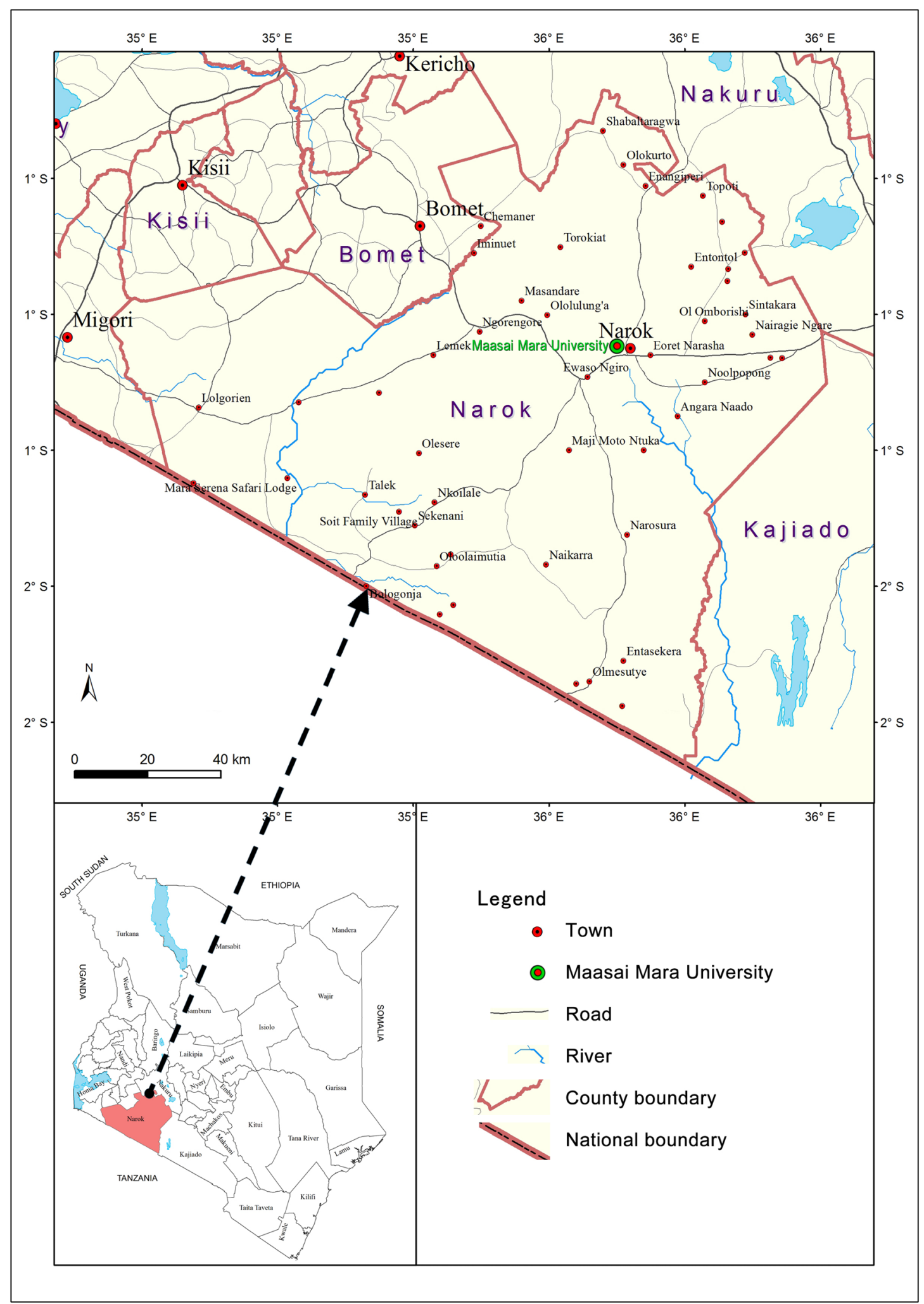

Fig. 1 Map of Kenya indicating the location of the study site in Narok County at the African Medicinal Botanical Garden (AMBG) of the Maasai Mara University 


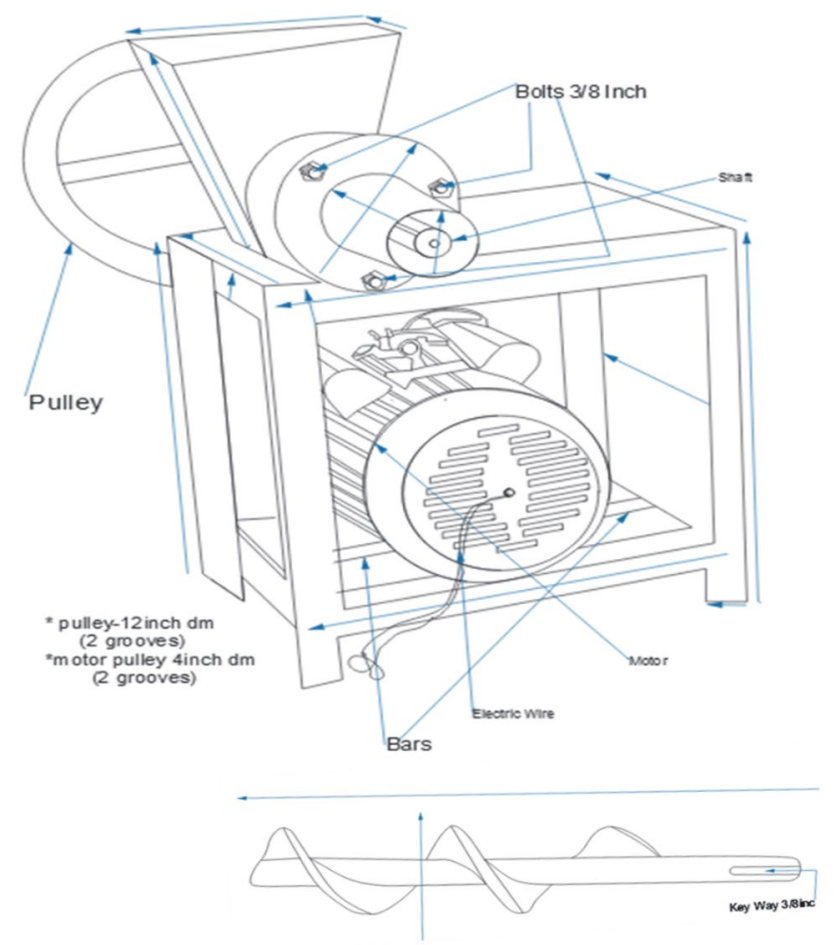

Fig. 2 The architectural layout design of the locally fabricated briquetting machine together with its rotating shaft

dry biomass (about $192 \mathrm{~kg}$ ) was subjected to mechanical crushing using a mechanical grinder into a powder.

Phytoplankton scum was harvested using scoop nets from the aquatic sections of the African Medicinal Botanical Garden (AMBG), sundried for a week and then pulverized where about $10 \mathrm{~kg}$ was obtained. Twenty liters of molasses liquid was also purchased from the local sugar milling company of Miwani Sugar Company Limited to be used as a binder too during the production of fuel briquettes. Dried leaves of $E$. globulus were also collected around the AMBG and ground into powder too, also to be used as a binder. The phytoplankton scum powder, molasses and powder of the leaves of E. globulus were used separately as binders to improve compactness and strength of the fuel briquettes. Masses of $10 \%, 20 \%$ and $30 \%$ binders to the chopped and ground E. crassipes were used to establish the sufficient binder ratio for efficient and effective compact fuel briquettes. That is, ratios of 9:1, 4:1 and 3:1 E. crassipes to binder ratios were used for each of the binders utilized. Each sample was well manually mixed with about $2 \mathrm{~L}$ of water until a dense mass with the ability to be compacted was obtained [1] before being poured into the locally manufactured screw press space of the fuel briquette machine (Fig. 2). The biofuel briquettes made were analyzed for their compressed density before being sundried for 3 weeks and thereafter, their relaxed density, water resistance capacity, durability and calorific value were evaluated.

\subsection{Step by step process of producing biofuel briquettes}

The step by step process of producing the briquettes is shown in Fig. 3 as explained below.

Step 1 The production process began with the manual harvesting of E. crassipes from the Maasai Mara University Wastewater Effluent Management System [21]. The old plants that showed signs of patched leaves and darkened roots were selectively removed leaving the younger plants that functioned much better in cleaning the dirty water.

Step 2 Physical shredding of E. crassipes biomass into small pieces using machetes.

Step 3 The cut pieces of $E$. crassipes were spread in the open for sun drying [16].

Step 4 The dried biomass was then ground into powder using a mechanical grinder [29], sieved using a mesh to a particle size of $<5 \mathrm{~mm}$ and mixed with binders of ground E. globulus leaves powder, molasses and phytoplankton scum at ratios of 10:90, 20:80 and 30:70 binders to the $E$. crassipes biomass ratio. The addition of binder into biobriquette enhances its properties [30]. Mixing was thoroughly done by hand while adding water of about 2 litres of water [4] per $5 \mathrm{~kg}$ mixture until a satisfactory mixture was achieved.

Step 5 The mixture of E. crassipes, binder and water was poured into the holding area of the biofuel briquette machine. The machine compressed the biomass to achieve the desired fuel briquettes at the nozzle end of the briquetting machine.

Step 6 The resultant biofuel briquettes removed from the briquetting machine were analyzed for their compressed density and subsequently subjected to sun drying for about 3 weeks. After 3 weeks, further laboratory tests were carried out to measure other parameters such as relaxed density, relaxation ratio, durability, water resistance capacity and calorific values.

Step 7These biofuel briquettes were ready for use after laboratory tests.

\subsection{Evaluation of the quality of biofuel briquettes}

Quality evaluation was conducted to ensure the fuel briquettes are not affected during handling, storage and transportation. Parameters such as the compressed density, relaxed density, durability, water resistance capacity and calorific values were studied. 


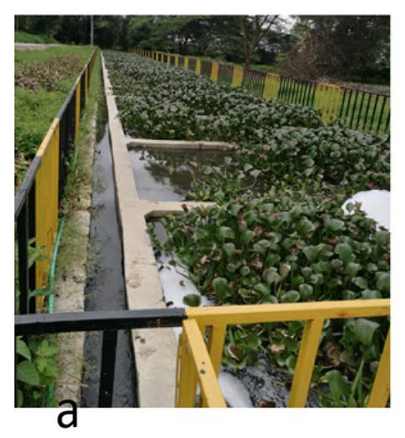

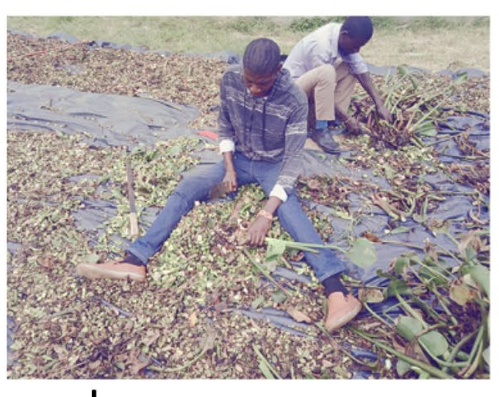

b

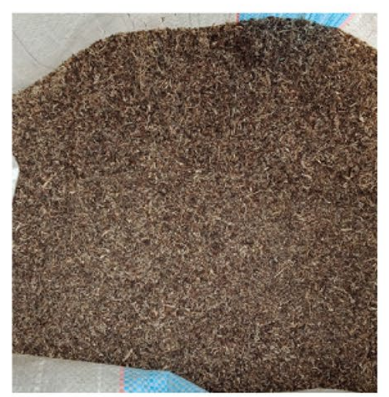

C

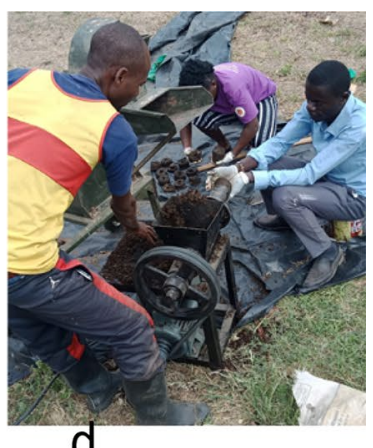

d

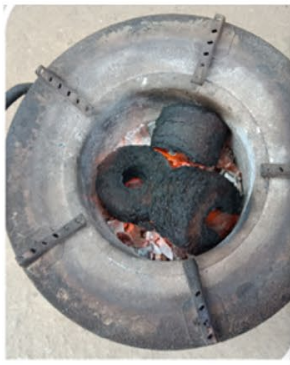

g

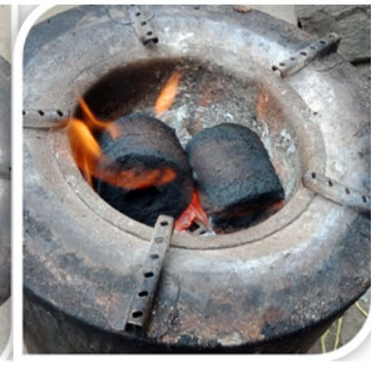

(n)

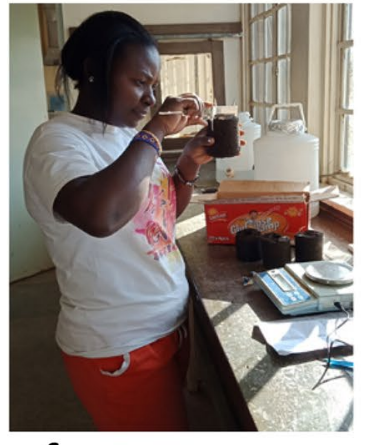

$f$

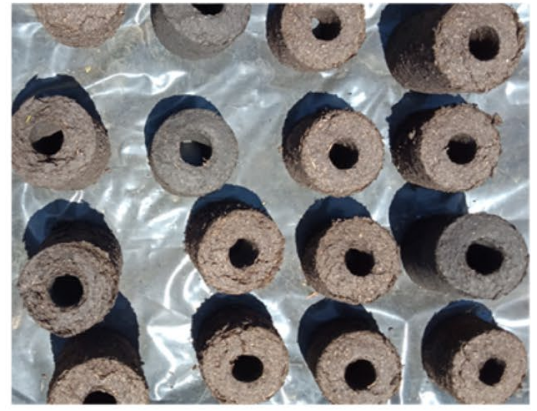

e
Fig. 3 The activities taking place in the various steps above are as follows: a fresh E. crassipes in sewer cleaning ponds b physical chopping and sun-drying of harvested $E$. crassipes $\mathbf{c}$ dried, crushed and sieved $E$. crassipes $\mathbf{d}$ mixed biomass poured into the briquette

\subsubsection{Compressed density}

The compressed density of the biofuel briquettes was determined immediately after removal from the briquette machine [23] as a ratio of measured weight over calculated volume. Highly compressed biofuel briquettes give low burning rates and therefore are good quality [28]. The mass of the biofuel briquettes was determined using Shimadzu-ELB300 (max. $300 \mathrm{~g}, \mathrm{~d}=0.01 \mathrm{~g}$ min. $0.2 \mathrm{~g}$ ) electronic balance. The diameters of the sample fuel briquettes were measured at three points, top, center and bottom. The length was also measured at three points using a Vernier caliper. Compressed density was calculated as a ratio of measured weight over calculated volume according to American Society of Agricultural and Biological Engineers (ASABE) standards, which outlines technical standards for commercial biofuel briquette production [13] as shown in the Eq. (1) below:

Compressed density $=($ Measured Weight $) /($ Calculated Volume $)$.

The calculated volume was measured by getting the external and internal diameters of briquette at three points, respectively, measured in millimeters. The biofuel machine and processed into fuel briquettes e processed fuel briquettes being sundried $\mathbf{f}$ laboratory testing of the briquettes $\mathbf{g}$ biofuel briquettes burning on an eco-jiko

briquette length was also measured at three points measured in millimeters and the mass of biofuel briquette in grams was also measured using an electronic balance. Three replicates were used.

\subsubsection{Relaxed density}

The relaxed density of the biofuel briquettes was determined 21 days after removal from the press and drying. The procedure for determining relaxed density was similar to that of determining compressed density. Three replicates were used too [30]. The mass of these three was measured using Shimadzu-ELB300 (max. $300 \mathrm{~g}, \mathrm{~d}=0.01 \mathrm{~g}$ min. $0.2 \mathrm{~g}$ ) electronic balance and recorded. On each sample biofuel briquette, the internal and external diameters were measured at three points and recorded. The biofuel briquettes height was also measured at 3 points and the average obtained. These were also used to calculate their volumes. The relaxed density was calculated as a ratio of the biofuel briquette mass in grams to its volume in $\mathrm{cm}^{3}$ and according to Brunerová et al. [13]. The average of the three replicates represented the relaxed density of the fuel briquette sample under study. This was repeated on all the biofuel briquette sample types for analysis. 


\subsubsection{Relaxation ratio}

The relaxation ratio was calculated from compressed and relaxed densities. The relaxation ratio was calculated as a ratio of the compressed density $(C D)$ to relaxed density (RD). A high relaxation ratio is an indication of good dimensional stability of the fuel briquette (the product is good if the ratio is approaching one). Relaxation ratio showed the stability of the biofuel briquette in shape, structure and form after production. A high relaxation ratio indicated stable biofuel briquette structures as previously shown [13, 31, 32].

The formula for calculating relaxation ratio (Eq. 2) is as follows:

Relaxation Ratio $=($ Compressed Density $) /($ Relaxed Density $)$.

\subsubsection{Durability}

This is the ability of a biofuel briquette to withstand mechanical handling. Durability minimizes damages and losses, especially during transportation and handling. It is a function of moisture content and density [1]. The test was done after 2 weeks from the time the biofuel briquette was produced according to [23]. The test was done by dropping a biofuel briquette, put in a polythene bag, from a height of $2 \mathrm{~m}$ on concrete surface three times. After dropping, the biofuel briquette and the fractions were sieved through a $35 \mathrm{~mm}$ mesh screen. Durability rating was then determined by calculating the ratio of the weight of material retained on the screen, $W_{2}$, to the weight of the biofuel briquette before dropping, $\mathrm{W}_{1}$. This is illustrated in Eq. (3).

Durability index $(\%)=\left[W_{2} / W_{1}\right] \times 100$.

\subsubsection{Water resistance capacity}

Water-resistance capacity is the measure of water absorptive capacity when the biofuel briquette is immersed in water. This parameter examines the com- disintegration. Water resistance was determined by calculating the weight of a biofuel briquette using an electronic balance, before and after immersing it in a glass of water for $2 \mathrm{~min}$ [30]. This was replicated three times. The Eq. (4) was used;

Percentage weight gain by biofuel briquette (\%)

$=\left(W_{2}-W_{1}\right) /\left(W_{1}\right) \times 100$

where $W_{1}=$ initial weight of the fuel briquette, $g$, and therefore,

Percentage resistance of water penetration (\%)

$=100-\%$ water gain

\subsubsection{Calorific value (CV)}

Calorific value (CV) is the amount of heat energy produced when a kilogram of fuel is burnt, measured in kilojoules per kilogram $(\mathrm{kJ} / \mathrm{kg})$ and is a very essential component of fuel. The $C V$ is perhaps one of the most important fuel aspects that informs the competitiveness of fuel on the market [28] and must be considered when selecting binders and raw materials for fuel briquette production. According to the principles of calorimetry, which states that heat liberated is equal to the heat gained, the heat liberated by the burning biomass briquette was assumed to be gained by the heated water shown by the temperature rise of the mass of water. For the measurement of the solid biofuels, a bomb calorimeter set up was used in determining the $\mathrm{CV}$ of the samples under study, where a known mass of water was subjected to heating using a known mass of the biomass fuel sample. The experiment was conducted in the open (in a room, not an enclosed oven) where it is expected that a substantial amount of heat may have been subsequently lost to the environment. The difference between the final and initial temperatures was used in calculating the fuel sample calorific values using the ASABE standard methods, which guide the principles of calorimetry.

The following formula (Eq. 5) was used

$C V=($ Heat generated $) /($ Mass of fuel $)$

Energy flow $(\mathrm{CV})=[$ Liquid Mass $\times$ Heat capacity $\times$ Temperature change $(\mathrm{kJ})] /[$ Mass of fuel $(\mathrm{Kg})]$

pressive strength of the briquette machine and also the nature of the material used in the manufacture of the biofuel briquette, which are key factors in determining the handling characteristics of the biofuel briquettes [4]. High absorption of water may lead to significant
$C V=Q=(m \times c \times d T) / M$

where $Q$ energy flow (calorific value), $m$ liquid mass, $c$ heat capacity, $d T$ temperature change, $M$ mass of fuel $(\mathrm{kg})$. 


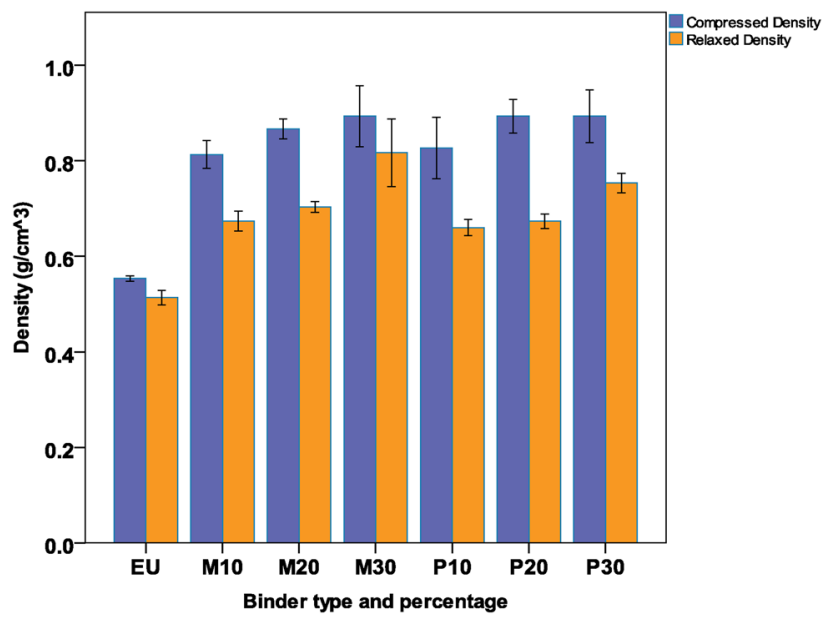

Fig. 4 The expression of compressed density (CD) and relaxed density (RD) of the biofuel briquettes. Where, $\mathrm{EU}=$ powder of Eucalyptus globulus leaves, $\mathrm{M}=$ molasses and $\mathrm{P}=$ phytoplankton scum as binders

Further CV comparisons were made with the results of other fuel briquettes made using three binders of human poop and carbonized sawdust, rice husks and sawdust as well as charcoal, which were analyzed for comparison of the CV.

\section{Results and discussion}

These results indicate an economic utilization of an invasive alien species, $E$. crassipes as part of its management strategy in the ecosystems by the Indigenous Peoples and Local Communities.

\subsection{Compressed and relaxed density of biofuel briquettes}

The biofuel briquettes made using Eucalyptus globulus (EU) as a binder exhibited a higher production temperature and had the lowest compressed and relaxed densities (Fig. 4). The compressed density of biofuel briquettes made using molasses (M) and phytoplankton scum $(\mathrm{P})$ as binders ranged from 0.8 to $0.89 \mathrm{~g} / \mathrm{cm}^{3}$ showing little distinct differences in the samples. The binding ratios were found to have no significant effect on the compressed density hence contradicting the findings of Oroka and Akhihiero [32] that the compressed density was inversely proportional to binder proportions. These findings suggest that compressed density is a factor influenced more by the briquetting machine rather than the ratios of binder [28]. The relaxed densities also increased with the increase in binder ratios for both molasses and phytoplankton scum binders (Fig. 4). The increased binder ratios may have increased the molecular weight of the biofuel briquettes leading to increased densities. This concurs with the findings of previous authors [1,32].

\subsection{Relaxation ratios}

Relaxation ratio shows the stability of the biofuel briquette in shape, structure and form after production. These ratios are shown in Table 1. High relaxation ratio indicates stable biofuel briquette structures and a low relaxation ratio indicates unstable biofuel briquettes. The relaxation ratios were calculated according to previous authors [13, 31, 32].

The relaxation ratios ranged from 1.08 to 1.33 between the biofuel briquettes produced and evaluated. This general increase in the relaxation ratios is also indicated by other studies of biofuel briquettes made from $E$. crassipes and cow dung mixture whose relaxation ratio ranged from 1.52 to 1.71 and was attributed to binder particle bulk density [31]. The biofuel briquettes made using phytoplankton scum binder indicated lower relaxation ratios of 1.26, 1.33 and 1.19 compared to the biofuel briquettes obtained from E. crassipes and cow dung mixture, thus indicating that the biofuel briquettes were more stable in structure and form than them but less stable in structure and form than the biofuel briquettes made using binder samples of E. globulus leaves and molasses (Table 1). The most stable biofuel briquette sample, therefore, was that made using the E. globulus leaf powder as a binder (EU), with a
Table 1 The relaxation ratios of the biofuel briquettes made using different binders with different percentage compositions

\begin{tabular}{lllll}
\hline Type of binders & $\begin{array}{l}\text { Binder percent- } \\
\text { age }\end{array}$ & $\begin{array}{l}\text { Compressed } \\
\text { density }\end{array}$ & Relaxed density & $\begin{array}{l}\text { Relaxa- } \\
\text { tion } \\
\text { Ratio }\end{array}$ \\
\hline Eucalyptus globulus (EU) & 20 & 0.55 & 0.51 & 1.08 \\
Molasses (M) & 10 & 0.80 & 0.67 & 1.19 \\
& 20 & 0.87 & 0.70 & 1.24 \\
Phytoplankton Scum (P) & 30 & 0.89 & 0.82 & 1.09 \\
& 10 & 0.83 & 0.66 & 1.26 \\
& 20 & 0.89 & 0.67 & 1.33 \\
& 30 & 0.89 & 0.75 & 1.19 \\
\hline
\end{tabular}


Fig. 5 The percentage durability of the biofuel briquettes made using different binders. Where, $R \& S=$ rice husks and sawdust binder, HP\&CS = human poop and carbonized sawdust binder, $\mathrm{EU}=$ powder of Eucalyptus globulus leaves binder, $\mathrm{M}=$ molasses binder and $\mathrm{P}=$ phytoplankton scum binder

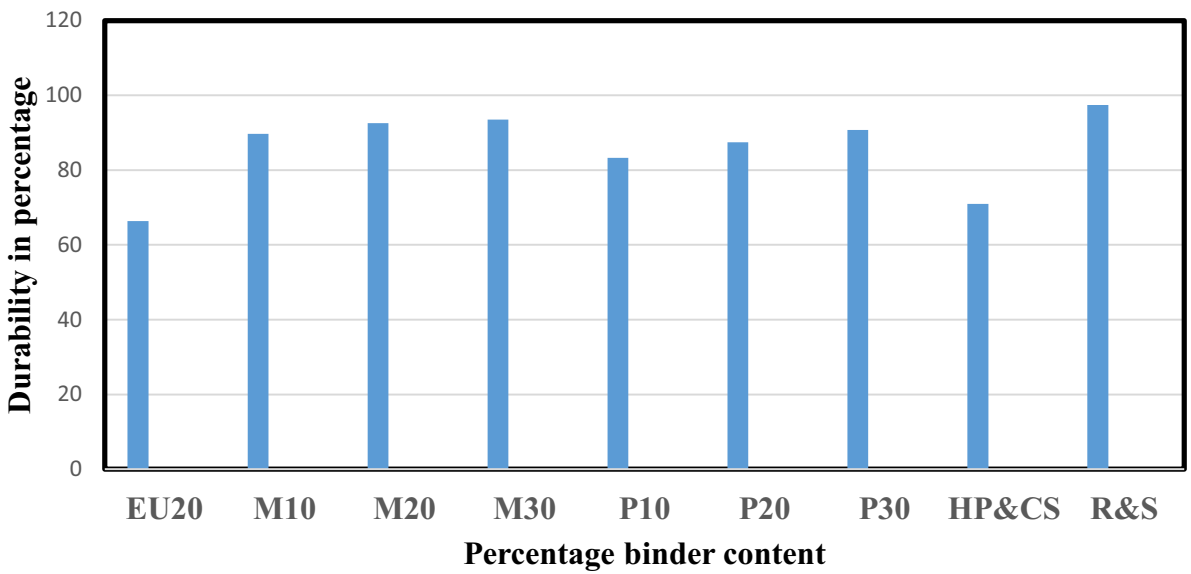

relaxation ratio of 1.08 . The quality is good when the ratio is approaching 1.

\subsection{Water resistance capacity of the biofuel briquettes}

When immersed in water, biofuel briquette mass increased from 166.3 to $258.93 \mathrm{~g}$ representing a $55 \%$ mass increase. The percentage water-resistance capacity is therefore $45 \%$. This indicates an average water-resistance ability. These biofuel briquettes would preferably be useful in drier areas as high humidity may lead to easy disintegration. In high humid areas, this research recommends a briquetting machine with a high compressive strength when the choice of the raw material is E. crassipes.

\subsection{The durability of the biofuel briquettes}

Durable products can withstand the vigor of transportation, handling and storage, which is an important aspect of biofuel briquettes. The percentage durability ranged from as low as $66.34 \%$ (E. globulus binder samples, EU20) to as high as $\mathbf{9 7 . 4 3 \%}$ (Rice husks and sawdust samples) (Fig. 5). This indicates that the E. globulus binder sample had high moisture content or poor compatibility between the binder material (powder of E. globulus leaves) and the raw material (E. crassipes). The biofuel briquettes made using rice husks and sawdust as binders had the highest biofuel briquette durability of $97.43 \%$ because of the low moisture content they contained and this is because of the high pressure exerted on the biomass during its production [18]. Durability also increased with the increase in binder ratios as shown by biofuel briquettes made using molasses (M) as a binder as well as phytoplankton scum binders (P) (Fig. 5). The results prove that binding agents improve the handling characteristics potential of $E$. crassipes briquettes. And these findings agree with the findings of the previous authors [25] that the handling characteristics of biofuel briquettes also depends on the nature and type of the binder and its proportion. The results also concurred with the previous findings that the relaxed density is directly proportional to the durability as durability increased with the increase in density [1].
Fig. 6 The calorific values (CV) of the biofuel briquettes made using different binders. Where, $R \& S=$ rice husks and sawdust binder, HP\&CS = human poop and carbonized sawdust binder, EU = powder of Eucalyptus globulus leaves binder, $\mathrm{M}=$ molasses binder and $\mathrm{P}=$ phytoplankton scum binder

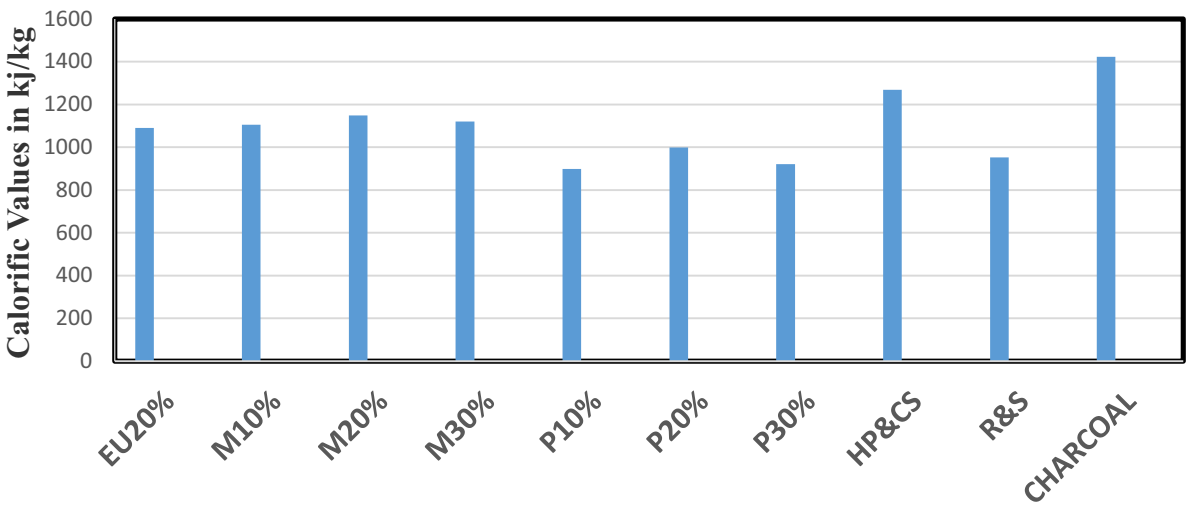

Percentage binder content 


\subsection{Calorific value (CV)}

According to the principles of calorimetry, heat liberated $=$ heat gained. The biofuel briquette samples were weighed and used to heat water to determine the CV of the biofuel briquettes. A known mass of each biofuel briquette sample was used to heat $2 \mathrm{~L}$ of water. The initial temperature of the water was recorded and the highest temperatures attained were also recorded. These were used in calculating the calorific values. The results were also compared to other 3 samples of biofuel briquettes made using human poop and carbonized sawdust (HP\&CS) and rise husks and sawdust (R\&S) as binders and also those biofuel briquettes made from charcoal, which were analyzed together for comparative analysis of their CVs (Fig. 6).

The biofuel briquettes made using binder samples of $10 \%$ phytoplankton scum recorded the lowest CV of $898.92 \mathrm{~kJ} / \mathrm{kg}$ indicating the lowest energy output among the fuel briquette samples studied. The biofuel briquettes made using the binder samples of $20 \%$ phytoplankton scum had a CV of $998.37 \mathrm{~kJ} / \mathrm{kg}$. High calorific values were recorded in the fuel briquettes made using binder samples of powder of $E$. globulus leaves and molasses compared to the fuel briquettes made using the binder samples of phytoplankton scum (Fig. 5). This indicates that molasses and powder of $E$. globulus leaves as binders improved the energy contents of the biofuel briquettes more in comparison to the phytoplankton scum as a binder.

The $20 \%$ binder ratios recorded the highest CV in either category of molasses and phytoplankton scum as binders, thus indicating that the optimum binder ratio to consider in the manufacture of biofuel briquettes may probably be $20 \%$ binder content when using either molasses or phytoplankton scum as binders and E. crassipes as the raw material. The addition of the powder of $E$. globulus leaves to the $E$. crassipes increased the energy output because the powder of E. globulus leaves contains oil, which is highly flammable. These leaves can be highly beneficial if incorporated in biomass fuel generation and reduce the risk of forest fires. By comparing to charcoal (purchased from the local market) which recorded a high CV of $1422.97 \mathrm{~kJ} /$ $\mathrm{kg}$, the $20 \%$ molasses content binder $(1148.35 \mathrm{~kJ} / \mathrm{kg})$ compared favorably with a difference of $274.62 \mathrm{~kJ} / \mathrm{kg}$, thus indicating that $E$. crassipes has the potential to compete economically with charcoal and other biofuel briquette products in the market such as those made using human poop and carbonized sawdust whose briquettes recorded a CV of $1267.78 \mathrm{~kJ} / \mathrm{kg}$.

The $30 \%$ binder ratios of molasses and phytoplankton scum recorded higher densities of 0.82 and 0.75 respectively but recorded low calorific values of $1120.89 \mathrm{~kJ} / \mathrm{kg}$ and $920.36 \mathrm{~kJ} / \mathrm{kg}$, respectively. When binders are added, the density increases as well as the durability of the biofuel briquette but the calorific values are achieved at an optimum content binder level, which, in the results obtained it was found to be at $20 \%$ content binder. When the optimum binder level is reached, further increase in density, therefore, decreases the ignitability of fuel briquettes.

\section{Summary}

The objective of the study was to investigate the production of bio briquettes from $E$. crassipes. The plant was harvested from the wastewater effluent management system, chopped, sun-dried and pulverized to a particle size of $<5 \mathrm{~mm}$ and mixed with various binders (Eucalyptus globulus leaves powder, molasses and phytoplankton scum). The powder of E. globulus leaves as a binder acted as an ignition enhancer to $E$. crassipes biofuel briquettes as they improved the calorific value due to the highly flammable E. globulus oil present in the leaves and therefore should be considered in the production of biofuel briquettes. When binder amounts were increased, the biofuel briquette strength increased, indicating that, the more the binder, the greater the biofuel briquette strength. The binders were found to have less effect on the compressed density but influenced the calorific values of the biofuel briquettes.

The biofuel briquettes made using the $20 \%$ molasses content binder would be best suited for domestic and cottage level industrial use as they exhibited good handling characteristics, as well as high calorific value compared to the other biofuel briquettes, made using the other percentage content and type of binders. The examined properties of the produced biofuel briquettes were satisfactory. This research, therefore, concludes that $E$. crassipes may become a viable raw material for producing quality biofuel briquettes that are durable with the desired calorific value and may withstand mechanical handling and be useful for household and cottage industries locally.

\section{Recommendations}

To increase the density of $E$. crassipes fuel briquettes, this research recommends the use of other binding agents such as red-clay soil, which is good for the heat retention and also for the density increment as binders currently used produced biofuel briquettes that are less dense though recorded good calorific value. Innovative $E$. crassipes resource utilization technologies such as hightemperature compost should be applied to realize the full potential of $E$. crassipes biomass fuel. 
Acknowledgements We acknowledge Wuhan Botanical Garden, Chinese Academy of Sciences and the University of Chinese Academy of Sciences for the funding of this research work and Maasai Mara University through The Institute of Ethnobiology and Ethnomedicines for providing the enabling research environment, management and research materials in the African Medicinal Botanical Garden. The authors of the manuscript wish to take this opportunity and thank the two reviewers most sincerely for helping to weed out the many mistakes in the manuscript during the reviewing period.

\section{Compliance with ethical standards}

Conflict of interest The authors declare no conflict of interest.

\section{References}

1. Carnaje NP, Talagon RB, Peralta JP, Shah K, Paz-Ferreiro J (2018) Development and characterisation of charcoal briquettes from water hyacinth (Eichhornia crassipes)-molasses blend. PLoS One 13(11):1-14

2. VonBank JA, Casper AF, Pendleton JE, Hagy HM (2018) Water hyacinth (Eichhornia crassipes) invasion and establishment in a temperate river system. River Res Appl 34(10):1237-1243. https ://doi.org/10.1002/rra.3362

3. Jones JL, Jenkins RO, Haris PI (2018) Extending the geographic reach of the water hyacinth plant in removal of heavy metals from a temperate Northern Hemisphere river. Sci Rep 8(1):1-15

4. Ojo EO, Okwu M, Edomwonyi-Otu L, Oyawale FA (2019) Initial assessment of reuse of sustainable wastes for fibreboard production: the case of waste paper and water hyacinth. J Mater Cycles Waste Manag 21(5):1177-1187. https://doi.org/10.1007/ s10163-019-00871-z

5. Bote MA, Naik VR, Jagdeeshgouda KB (2020) Production of biogas with aquatic weed water hyacinth and development of briquette making machine. Mat Sci Energy Technol 3:64-71. https://doi.org/10.1016/j.mset.2019.09.001

6. Mandal RA, Jha PK, Krakaue N, Jha A, Lakhankar T (2017) Assessing cost effective management options of Eichhornia crassipes in eco-tourism Ramsar site, Nepal. Int J Agric Sci Res Technol Ext Educ Syst (IJASRT in EESs) 7(2):79-83

7. Sharma A, Aggarwal NK, Saini A, Yadav A (2016) Beyond biocontrol: water hyacinth-opportunities and challenges. J Environ Sci Technol 9(1):26-48. https://doi.org/10.3923/jest.2016.26.48

8. Kriticos DJ, Brunel S (2016) Assessing and managing the current and future pest risk from water hyacinth (Eichhornia crassipes), an invasive aquatic plant threatening the environment and water security. PLoS One 11(8):1-18. https://doi.org/10.1371/ journal.pone.0120054

9. EL Souza C, Filho JT, Velini ED, Silva JRM, Tonello KC, Foloni LL, Freato TA (2020) Water hyacinth control by glyphosate herbicide and its impact on water quality. J Water Resour Prot 12(01):6073. https://doi.org/10.4236/jwarp.2020.121004

10. Tobias VD, Conrad JL, Mahardja B, Khanna S (2019) Impacts of water hyacinth treatment on water quality in a tidal estuarine environment. Biol Invasions 21(12):3479-3490. https://doi. org/10.1007/s10530-019-02061-2

11. Akers RP, Bergmann RW, Pitcairn MJ (2017) Biological control of water hyacinth in California's Sacramento-San Joaquin River Delta: observations on establishment and spread. Biocontrol Sci Technol 27(6):755-768. https://doi.org/10.1080/09583 157.2017.1342220

\section{SN Applied Sciences}

12. Dennis B, Alice AK, John BT, John M, John MM, Omwoyo O, Dative M (2018) Agronomic effectiveness of water hyacinthbased composts. Afr J Agric Res 13(39):2055-2062. https://doi. org/10.5897/ajar2018.13440

13. Brunerová A, Brožek M, Šleger V, Nováková A (2018) Energy balance of briquette production from various waste biomass. Sci Agric Bohem 19:236-243. https://doi.org/10.2478/ sab-2018-0030

14. Madian HR, Sidkey NM, Abo Elsoud MM, Hamouda HI, Elazzazy AM (2019) Bioethanol production from water hyacinth hydrolysate by Candida tropicalis Y-26. Arab J Sci Eng 44(1):33-41. https://doi.org/10.1007/s13369-018-3247-6

15. Zhang Q, Weng C, Huang H, Achal V, Wang D (2016) Optimization of bioethanol production using whole plant of water hyacinth as substrate in simultaneous saccharification and fermentation process. Front Microbiol 6:1-9. https://doi.org/10.3389/ fmicb.2015.01411

16. Modestus OO, Olabisi Al, Boye TE, Benjamin EO (2016) Development of water hyacinth briquetting machine. Int J Sci Res Inf Syst Eng 2(1):2380-8128

17. Tasnim F, lqbal SA, Chowdhury AR (2017) Biogas production from anaerobic co-digestion of cow manure with kitchen waste and water hyacinth. Renew Energy 109:434-439. https://doi. org/10.1016/j.renene.2017.03.044

18. Atta AM, Mohamed NH, Hegazy AK, Moustafa YM, Mohamed RR, Safwat G, Diab AA (2020) Green technology for remediation of water polluted with petroleum crude oil: using of Eichhornia crassipes (Mart.) Solms combined with magnetic nanoparticles capped with myrrh resources of Saudi Arabia. Nanomaterials 10(2):262. https://doi.org/10.3390/nano10020262

19. Zhang Y, Zhang Z, Wang Z et al (2016) Bioremediation of eutrophic water by the controlled cultivation of water hyacinths. In: World Environmental and Water Resources Congress 2016: watershed management, irrigation and drainage, and water resources planning and management-papers from sessions of the proceedings of the 2016 World Environmental and Water Resources Congress. American Society of Civil Engineers (ASCE), pp 251-261. https://doi.org/10.1061/9780784479858.027

20. Ruan T, Zeng R, Yin XY, Zhang SX, Yang ZH (2016) Water hyacinth (Eichhornia crassipes) biomass as a biofuel feedstock by enzymatic hydrolysis. Bioresources 11(1):2372-2380. https://doi. org/10.15376/biores.11.1.2372-2380

21. Su W, Sun Q, Xia M, Wen Z, Yao Z (2018) The resource utilization of water hyacinth (Eichhornia crassipes [Mart.] Solms) and its challenges. Resources 7(3):46. https://doi.org/10.3390/resou rces7030046

22. Merry M, Mitan N (2019) Water hyacinth: potential and threat. Mater Today Proc 19:1408-1412. https://doi.org/10.1016/j.matpr .2019.11.160

23. Okia DO, Ndiema CK, Ahmed MS (2016) Physical and chemical properties of water hyacinth based composite briquettes. Sci Res J IV (Xi):28-36

24. Okwu MO, Samuel OD (2018) Adapted hyacinth briquetting machine for mass production of briquettes. Energy Sources Part A Recovery Util Environ Effects 40(23):2853-2866. https://doi. org/10.1080/15567036.2018.1512681

25. Borowski G, Stẹpniewski W, Wójcik-Oliveira K (2017) Effect of starch binder on charcoal briquette properties. Int Agrophys 31(4):571-574. https://doi.org/10.1515/intag-2016-0077

26. Asamoah B, Nikiema J, Gebrezgabher S, Odonkor E, Njenga $M$ (2016) A review on production, marketing and use fuel briquettes. Resource recovery and reuse series 7 . https://doi. org/10.5337/2017.200

27. Muazu RI, Stegemann JA (2017) Biosolids and microalgae as alternative binders for biomass fuel briquetting. Fuel 194:339347. https://doi.org/10.1016/j.fuel.2017.01.019 
28. Okwu MO, Emovon I (2018) Comparative performance and analysis of fuel briquette produced from water hyacinth plant with paraffin oil. J Adv Eng Technol 6(2):1-6

29. Oyejide OJ, Okwu MO, Tartibu LK (2019) Adaptive design and development of a modular water hyacinth briquette stove. Energy Sour Part A Recovery Util Environ Effects 00(00):1-19. https://doi.org/10.1080/15567036.2019.1675808

30. Rezania S, Fadhil M, Fatimah S (2016) Evaluation of water hyacinth (Eichhornia crassipes) as a potential raw material source for briquette production. Energy 111:768-773. https://doi. org/10.1016/j.energy.2016.06.026
31. Davies RM, Davies OA (2013) Physical and combustion characteristics of briquettes made from water hyacinth and phytoplankton scum as binder. J Combust. https://doi. org/10.1155/2013/549894

32. Oroka FO, Akhihiero ET (2013) Fuel briquettes from water hyacinth-cow dung mixture as alternative energy for domestic and agro-industrial applications. J Energy Technol Policy 3(6):56-62

Publisher's Note Springer Nature remains neutral with regard to jurisdictional claims in published maps and institutional affiliations. 